\title{
ANALYSIS OF THE IMPACT OF APPLICATION OF FUELS WITH ADDITION OF BIOCOMPONENTS ON FUNCTIONING OF TRANSPORT MEANS
}

\author{
Analiza wpływu stosowania paliw $\mathrm{z}$ dodatkiem \\ biokomponetów na funkcjonowanie środków \\ transportowych
}

\begin{abstract}
The study describes a method and a model for assessment of the impact of addition of fatty acid methyl esters to fuel oil on selected parameters of transport means. For this purpose, criteria for assessment of operational parameters of the analyzed mixture have been identified. A model has been developed to find out how the values of the analyzed parameters reflect the state of transport means powered by fuel oil mixtures and methyl esters offatty acids. Ten operational parameters have been accepted for the research object description. The parameter values were measured depending on the analyzed mixture composition. The obtained results allowed to determine the components of the object state vector. The developed model has been verified by application of the method of mean fuzzy diagram.
\end{abstract}

Keywords: fuel oil, biocomponent, operational parameters, assessment model, diagram of fuzzy means

Streszczenie: W pracy opisano metodę i zbudowano model ocenowy wplywu dodatku estrów metylowych kwasów tluszczowych do oleju napędowego na wybrane wartości parametrów uzytkowych środków transportowych. Wyznaczono kryteria oceny stanu badanych parametrów i mieszanek oraz zbudowano model, $w$ którym badane wartości parametrów odzwierciedlaja stan środków transportu zasilanych takimi mieszankami. Dokonano pomiaru wartości tych parametrów, w zależności od składu badanej mieszanki. Wyniki oceny pozwolity na wyznaczenie poszczególnych składowych wektora stanu obiektu. Opracowany model zweryfikowano metoda wykresów średnich rozmytych.

Słowa kluczowe: olej napędowy, biokomponent, parametry użytkowe, model ocenowy, wykres średnich rozmytych 


\section{Introduction}

The study provides an analysis of some aspects related to powering of self-ignition engines with mixtures of fuel oil and fatty acid methyl esters. Use of alternative fuels for powering combustion piston engines involves high demand for fuel which has a harmful impact on the natural resources [14]. Fuels of plant origin, which are the subject of this study, are commonly referred to as biofuels. Before they can be used to power engines, they must undergo chemical treatment to be provided with physical and chemical properties similar to those of a diesel oil. Rape oil is most commonly used due to its economic, technical and structural benefits. To make it suitable to power engines it must undergo the process of chemical treatment ZS [2-8,11,15,19-21].

The goal of this study is to provide a resultant model for assessment of the impact of fatty acid methyl esters added do a diesel oil on selected values of performance parameters of transport means.

\section{Research object and subject}

The material used for tests were plant oils subjected to the process of transesterification, commonly referred to as biocomponents, which were mixed in different proportions with diesel oil. The goal of the tests was to establish performance parameters of a transport means drive unit powered (I) and unit powered with variable mixtures of fatty acid methyl ester additives, in the following proportions: $10 \%, 30 \%, 50 \%$ and $50 \%$ with addition of a fuel additive (mixture II $-\mathrm{V}$ ). The tests involved examining parameters such as: power, torque, composition of exhaust gases, content of particulate matter in exhaust fumes and measuring noise emitted by the drive unit. Mixtures of diesel oil and fatty acid methyl esters were prepared in required proportions. A fuel additive which was added to the mixture of $50 \%$ diesel oil and 50\% fatty acid methyl esters was an octane number and fuel lubrication enhancement additive.

The research object is a self-ignition engine with Common Rail direct fuel injection with electromagnetic injectors. The tested engines equipped with a dual mass flywheel and a variable turbine geometry turbocharger to enhance the performance parameters and meet rigorous exhaust emission norms. The drive unit used for the tests was not equipped with a particulate matter filter. The tested 16 valve engine marked as $1.6 \mathrm{HDi}$ has a timing belt which is powered by one camshaft, whereas power is transmitted to a second shaft by means of a chain. The fuel supply system of the research object was adjusted so that fuel could be changed without impacting the engine operation [12]. 


\section{Construction of the assessment model}

An analysis of the subject literature and the authors' own research shows $[1,9,11,13]$ that assessment of functioning of transport means fueled by mixtures of diesel oil and fatty acid methyl esters should be carried out with the use of significant performance parameters (characteristics), expressed by means of their numerical values. The tested parameters to be accepted in the formal mathematical description of the model are those which have significant impact on the research results.

The assessment process involves identifying a set $\left\{\mathrm{X}_{\mathrm{i}}\right\} \quad i=1,2, \ldots, p$ parameters (characteristics) to describe the research object from the point of view of the research goal. Next, the value of each accepted parameter (measurable characteristics) is measured or the state they are in is defined (non-measurable characteristics) by assigning to them appropriate determiners. Based on this it is possible to determine the operating state of a transport means drive unit powered with mixtures of diesel oil and fatty acid methyl esters.

Let $X_{i}, i=1,2, \ldots, p$, denote a characteristic being a random variable which reflects assessment of a transport means functioning from the point of view of its being powered with a fuel mixture. A vector of characteristics is considered in the form:

$$
\mathrm{X}=<\mathrm{X}_{1}, \mathrm{X}_{2}, \ldots, \mathrm{X}_{\mathrm{p}}>
$$

Component $X_{i}, i=1,2, \ldots, p$, vector $X$, is one dimensional random variable in $\boldsymbol{R}$ space, describing the $i$-th characteristic, reflecting the value of one of the parameters accepted for the assessment.

Whereas vector $X$ is a $p$-dimensional random variable which provides an overall description of the research object assessment in space.

A random variable is defined for a given research object in the form:

$$
Z_{x}=\sum_{i=1}^{p} \alpha_{i} X_{i}
$$

where:

$\alpha_{i} \geq 0, \sum_{i=1}^{p} \alpha_{i}=1$,

$\alpha_{i}, i=1,2, \ldots, p-$ denote values of weights for particular parameters,

$Z_{X}$ - is a random variable being a mixture of variables $X_{i}, i=1,2, \ldots, p$.

AHP (Analytic Hierarchy Process) was used for determination of particular criteria weights in the assessment process $[10,18]$.

The study involves a comparative assessment of the transport means, powered with different mixtures, in reference to a normalized mixture or one accepted as a reference point. It needs to be noticed that the values of parameters describing the tested specimens need to be lower, equal or higher than the values of parameters which are assumed to be the reference point. In such a case, in graphic interpretation, the lengths of the vector components can be analogical or different from the lengths of the vector components and 
the overall assessment will be the effect of summary values of particular parameters and assigned to them weights.

One dimensional vectors, accepted to be random variables, were denoted with variable $X$. The tested parameters $\left(X_{1} \div X_{10}\right)$, presented in table 1 , reflect assessment of transport means powered with mixtures of diesel oil and fatty acid methyl esters. Then, the considered vector had the form:

$$
\mathrm{X}_{\mathrm{i}}=<\mathrm{X}_{1}, \mathrm{X}_{2}, \mathrm{X}_{3}, \mathrm{X}_{4}, \mathrm{X}_{5}, \mathrm{X}_{6}, \mathrm{X}_{7}, \mathrm{X}_{8}, \mathrm{X}_{9}, \mathrm{X}_{10}>
$$

A random variable was defined for the research object assuming the form:

$$
Z_{x}=\alpha_{1} X_{1}+\alpha_{2} X_{2}+\alpha_{3} X_{3}+\alpha_{4} X_{4}+\alpha_{5} X_{5}+\alpha_{6} X_{7}+\alpha_{7} X_{7}+\alpha_{8} X_{8}+\alpha_{9} X_{9}+\alpha_{10} X_{10}
$$

where $\alpha_{i}$ is used to denote the values of weights of particular parameters which are presented in table 1.

Table 1

Values of weights for particular parameters

\begin{tabular}{|c|c|l|l|}
\hline Parameters & Denotation & \multicolumn{1}{|c|}{ Explanation } & Weight \\
\hline $\mathrm{X}_{1}$ & $\alpha_{1}$ & power [kW] & 0.2616 \\
\hline $\mathrm{X}_{2}$ & $\alpha_{2}$ & torque [Nm] & 0.45547 \\
\hline $\mathrm{X}_{3}$ & $\alpha_{3}$ & emission of noise generated by drive unit [dB] & 0.01239 \\
\hline $\mathrm{X}_{4}$ & $\alpha_{4}$ & particulate matter content in exhaust emissions [ppm] & 0.2616 \\
\hline $\mathrm{X}_{5}$ & $\alpha_{5}$ & Carbonoxide [\% vol.] & 0.00044 \\
\hline $\mathrm{X}_{6}$ & $\alpha_{6}$ & Carbondioxide [\% vol.] & 0.00235 \\
\hline $\mathrm{X}_{7}$ & $\alpha_{7}$ & oxygen [\% vol.] & 0.00046 \\
\hline $\mathrm{X}_{8}$ & $\alpha_{8}$ & nitricoxides [ppm] & 0.00539 \\
\hline $\mathrm{X}_{9}$ & $\alpha_{9}$ & air-fuel-ratio lambda & 0.00019 \\
\hline $\mathrm{X}_{10}$ & $\alpha_{10}$ & hydrocarbons [ppm] & 0.00011 \\
\hline
\end{tabular}

Mean values of particular parameters were determined according to the test results, depending on the fuel mixture.

The values determined for the considered parameters were re-coded in such a way that minimal values represented the lowest level, whereas maximal values represented the desired value of each parameter.

For the purpose of clarity and equivalence of results, values of the analyzed parameters were normalized to interval $<0 \div 10>$, using the following dependency: 


$$
10 \times \frac{\left(X_{i}-X_{\min }\right)}{\left(X_{\max }-X_{\min }\right)}
$$

This provided the basis for determination of the values of vectors for particular performance parameters of the tested unit to be later compared with the values of 'pure diesel oil', being the reference point of this study.

Exemplary interpretation of results in a graphic form for mixture II, is presented in figure 1 .

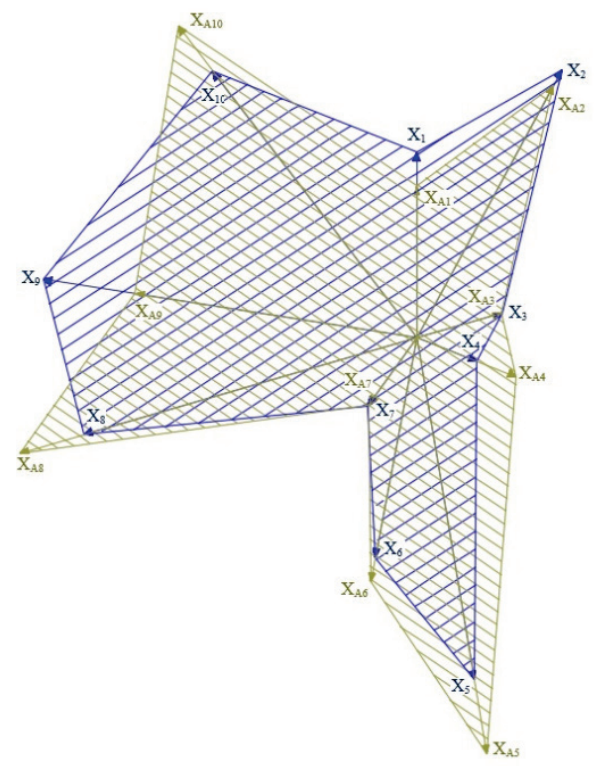

Fig. 1. Graphic interpretation of the vector components for mixture II

\section{Verification of the model}

One of the major problems involved in the proposed assessment method is to identify only those parameters which would have the biggest impact on the assessment and would provide the basis for further analyses. A set of ten parameters was identified to be used in the resultant model. Having in mind verification of the model, especially redundancy of the accepted parameter set and determination of their significance, it is proposed to use the method of diagrams of fuzzy means. An analysis of the performance parameter values determined in the tests was used for the process of fuzzy modeling. A cross-section was determined for selected values of each accepted parameter, for the variable established value $[13,16]$. 
In order to analyze real data, the value determined for the cross-section was fuzzed with measurement points. This eliminates the problems connected with non-uniform and discontinuous coverage of the solution space. Belonging of a measurement point to a given cross-section was accepted to be in the form of Gaussian function:

$$
\mu\left(X_{i}^{*}\right)=\exp \left(-\left(\frac{X_{i}^{*}-X_{i}}{b}\right)^{2}\right)
$$

where:

$\mu\left(X_{i}^{*}\right)$ - membership function for the established value of the $i$-th parameter,

$X_{i}^{*} \quad-$ established value of the $i$-th parameter,

$B \quad-$ width of a membership function opening.

Weighted mean value was calculated for each cross-section:

$$
Z_{\dot{s} r}\left(X_{i}\right)=\frac{\sum_{k=1}^{n w p} \mu\left(X_{k}\right) \times Z\left(w p_{k}\right)}{\sum_{k=1}^{n w p} \mu\left(X_{k}\right)}
$$

where:

nwp - number of measurement vectors,

wp - measurement vector.

Mean values of cross-sections make up a curve whose scatter is a measure of the output value dependence degree on the input value.

An analysis was carried out with the use of software [17], adjusted to the needs of this study. A membership function span coefficient was accepted to be $20 \%$. The number of fuzzy cross-sections equal to 10 and a method for scatter calculation were established as a mean square value. Based on the analysis, the significance limit was found to be 0.01 . Equal weights were determined for all the tested performance parameters. Next, it was defined which parameters were the most significant in terms of the carried out experiment. The obtained results were analyzed through determination of a fuzzy mean in order to identify change responsive performance parameters. In figure 2 there is a spectral form of fuzzy means, Based on an analysis of the data obtained from the experiment and its interpretation it can be assumed that performance parameters whose scatter value is smaller than 0.04 do not undergo significant change depending on the type of fuel which is used to power the drive unit of the tested transport means. 




Fig. 2. Spectral form of fuzzy means

The values of scatters for particular performance parameters defining their sensitivity to the fuel mixture content are presented in table 2 .

Table 2

Values of fuzzy average scatter for particular performance parameters

\begin{tabular}{|l|c|c|}
\hline \multicolumn{1}{|c|}{ Kind of parameter } & Denotation & Scatter value of fuzzy mean \\
\hline Power [kW] & $\mathrm{X}_{1}$ & 0.0035 \\
\hline Torque [Nm] & $\mathrm{X}_{2}$ & 0.0019 \\
\hline Noise [dB] & $\mathrm{X}_{3}$ & 0.0012 \\
\hline Particulatematter [ppm] & $\mathrm{X}_{4}$ & 0.0002 \\
\hline Carbon oxide [\% vol.] & $\mathrm{X}_{5}$ & 0.0755 \\
\hline Carbon dioxide[\% vol.] & $\mathrm{X}_{6}$ & 0.0138 \\
\hline Oxygen [\% vol.] & $\mathrm{X}_{7}$ & 0.1353 \\
\hline Nitricoxides[ppm] & $\mathrm{X}_{8}$ & 0.0605 \\
\hline Airfuel ratio & $\mathrm{X}_{9}$ & 0.0029 \\
\hline Hydrocarbons [ppm] & $\mathrm{X}_{10}$ & 0.0596 \\
\hline
\end{tabular}

The data presented in the table allow to find out which of the tested parameters was sensitive to the fuel mixture change and whether it can be neglected in further studies. 
The resultant form of the assessment model was verified by an analysis of data determined after application diagrams of fuzzy means. The resultant form of the assessment model was verified by means of an analysis of data determined after application of the method of fuzzy average diagrams. Based on this a set of six parameters was identified and included in further tests. They were characterized by a significant scatter of the result values. Values of the remaining performance parameters (power, torque, noise emission, particulate matter) were neglected in the developed model due to their low sensitivity to the fuel mixture content changes. Thus, the considered vector of $X_{i}$ parameters assumes the form:

$$
\mathrm{X}=<\mathrm{X}_{5}, \mathrm{X}_{6}, \mathrm{X}_{7}, \mathrm{X}_{8}, \mathrm{X}_{9}, \mathrm{X}_{10}>
$$

\section{Conclusions}

An analysis of the above tests results has proved that the method of diagrams of fuzzy means is an important tool to be used in the analyzed assessment process.

The verification has revealed that initially assumed number of performance parameters accepted for assessment of the tested drive unit did not find reflection in their sensitivity to applied changes in the content of fuel additives to biocomponents. Hence, the obtained test results made it possible to establish significance of the considered parameters from the research point of view, limit dimensionality of the considered space - set of parameters and determine the resultant form of an assessment model. At the same time it should be noticed that the results of tests can provide benefits by reducing the costs and time of further research.

\section{References}

1. Aryanto D.: Research of Simple Multi-Attribute Rating Technique for Decision Support. JITEKH (Jurnal Ilmiah Teknologi Harapan), 2019, 1.

2. Asadia A., Zhangb Y., Mohammadi H., Khorand H., Rui Z., Hossein Doranehgard M., Bozorge M.: Combustion and Emission Characteristics of Biomass Derived Biofuel, Premixed in a Diesel Engine: A CFD Study. Renewable Energy, Vol. 138, 2019.

3. Baraniak M., Łaczek T.: Low temperature properties of biofuels containing fatty acid methyl esters of animal fat origin. Oil-Gas, 2010.

4. Beran E.: Chemical technology - Energy resources and methods. Wrocław University of Technology, 2013.

5. Fontaras G., Karavalakis G., Kousoulidou M., Tzamkiozis T., Ntziachristos L., Bakeas E., Stournas S., Samaras Z.: Effects of Biodiesel on Passenger Car Fuel Consumption, Regulated and Non-Regulated Pollutant Emissions Over Legislated and Real-World Driving Cycles. Fuel, Vol. 88, 2009. 
6. Gang W., Guohe J., Zhiyuan Y., Zhijian H.: Emission Characteristics for Waste Cooking Oil Biodiesel Blend in a Marine Diesel Propulsion Engine. Polish Journal of Environmental Studies, Vol. 28, 2019.

7. Jakóbiec J., Baranik M., Duda A.: High quality of fatty acid methyl esters of rape oil is a promotion of car transport. Archives of Motorization, Warsaw, 2008.

8. Landowski B., Baran M.: Analysis of selected results of engine oil tests. 18th International Conference Diagnostics of Machines and Vehicles, MATEC Web of Conferences, 302, 2019.

9. Landowski B., Pająk M., Żółtowski B., Muślewski Ł.: Method of building a model of operational changes for the marine combustion engine describing the impact of the damages of this engine on the characteristics of its operation process. Polish Maritime Research, no. 4 (96), vol. 24, 2017.

10. Lootsma F.A.: A model for the relative importance of the criteria in the multiplicative AHP and Smart. European Journal of Operational Research, No. 94, 1996.

11. Markiewicz M., Muślewski Ł., Pająk M.: Impact of Biocomponent Additive to Diesel Oil on Values of Selected Functional Parameters of Transport Means. Polish Journal of Environmental Studies, Vol. 29, 2020.

12. Markiewicz M., Muślewski Ł.: The impact of powering an engine with fuels from renewable energy sources including its software modification on a drive unit performance parameters. Sustainability, Vol. 11, Iss. 23, 2019.

13. Markiewicz M., Muślewski Ł.: Survey performance and emission parameters of diesel engine powered by diesel oil and fatty acid methyl esters using fuzzy logic techniques. Fuel, Vol. 277, 2020.

14. Mofijur M., Rasul M., Hyde J., Bhuyia M.: Role of Biofuels on IC Engines Emission Reduction. Energy Procedia, Vol. 75, 2015.

15. Radziemska E., Lewandowski W., Szukalska E., Tynek M., Pustelnik A., Ciunel K.: Rape biofuels, preparation of raw material to provide biocomponents under the conditions of an agricultural farm and pilot methanolysis. Metrologia, Gdańsk 2009.

16. Pająk, M.: Genetic-Fuzzy system of power units maintenance schedules generation. J Intell Fuzzy System, 28, 2015.

17. Pająk M., Muślewski Ł., Landowski B., Grządziela A.: Fuzzy identification of the reliability state of the mine detecting ship propulsion system. Polish Maritime Research, 26 (1), 2019.

18. Saaty T.L.: The analytic Hierarchy Process. Planning, priority setting and resource allocation. Mc. Graw-Hill, New York 1980.

19. Struś M.: Efficiency of self-ignition combustion engines powered with bioxdiesel with totally recyclable components, Machine Engineering, 2014.

20. Tys J., Piekarski W., Jackowska I., Kaczor A., Zając G., Starobrat P.: Technological and economic conditionings of rape biofuel production, Disputes and monographs, Lublin 2003.

21. Uzdowski M.: Possibilities of using mixtures of traditional and alternative fuels to power ZS engines. Motrol 8A, 2006. 


\section{ANALIZA WPLYWU STOSOWANIA PALIW Z DODATKIEM BIOKOMPONENTÓW NA FUNKCJONOWANIE ŚRODKÓW TRANSPORTOWYCH}

\section{Wprowadzenie}

W niniejszym opracowaniu poddano analizie wybrane aspekty zasilania silników z zapłonem samoczynnym mieszankami oleju napędowego i estrów metylowych kwasów tłuszczowych.

Stosowanie paliw alternatywnych do zasilania tłokowych silników spalinowych środków transportowych związane jest z wysokim zapotrzebowaniem na paliwa przy jednoczesnym zmniejszaniu się ich zasobów naturalnych [14]. Stanowiące przedmiot badań paliwa pochodzenia roślinnego, potocznie nazywane biopaliwami, poddane muszą być procesom chemicznym w celu uzyskania właściwości fizykochemicznych zbliżonych do oleju napędowego. Ze względów technicznych, ekonomicznych, konstrukcyjnych i technologicznych najczęściej stosowany jest olej rzepakowy, który poddawany jest procesowi chemicznej obróbki w celu dostosowania go do zasilania silników ZS [2-8, 11, 15, 19-21].

Celem pracy jest wyznaczenie modelu wynikowego oceny wpływu dodatku estrów metylowych kwasów tłuszczowych do oleju napędowego na wybrane wartości parametrów użytkowych środków transportowych.

\section{Obiekt i przedmiot badań}

Materiałem używanym podczas badań były oleje roślinne poddane procesowi transestryfikacji, potocznie nazywane biokomponentami, które mieszane były w różnych proporcjach z olejem napędowym. Badania podstawowe dotyczyły wartości parametrów użytkowych jednostki napędowej środka transportu zasilanego olejem napędowym (I) oraz oleju napędowego ze zmiennym dodatkiem estrów metylowych kwasów tłuszczowych, w proporcjach $10 \%, 30 \%, 50 \%$ oraz $50 \%$ z dodatkiem uszlachetniacza (mieszanki II-V). Badaniu poddane były takie parametry jak: moc, moment obrotowy, skład spalin, zawartość cząstek stałych w spalinach oraz emisja dźwięku generowanego przez jednostkę napędową.

Mieszanki oleju napędowego i estrów metylowych kwasów tłuszczowych przygotowane zostały $\mathrm{w}$ zaplanowanych proporcjach i odpowiednio oznaczone. Dodatkiem 
uszlachetniającym, który stosowany był w połączeniu z mieszanką 50\% oleju napędowego i 50\% estrów metylowych kwasów tłuszczowych był środek wzbogacający liczbę cetanową oraz zwiększający właściwości smarne paliwa.

Obiektem badań był silnik o zapłonie samoczynnym z bezpośrednim wtryskiem paliwa realizowanym przy pomocy systemu Common Rail z zastosowanymi wtryskiwaczami elektromagnetycznymi. Badany silnik współpracuje $\mathrm{z}$ dwumasowym kołem zamachowym oraz turbosprężarką o zmiennej geometrii łopatek, co wpływa na podniesienie generowanych osiągów oraz spełnia rygorystyczne normy emisji spalin. Jednostka napędowa używana w badaniach nie była wyposażona w filtr cząstek stałych. Badany silnik o oznaczeniu 1.6 HDi w wersji 16-zaworowej ma pasek rozrządu, który napędza jeden wałek rozrządu, a drugi wałek odbiera napęd od pierwszego za pośrednictwem łańcucha. W obiekcie badań dokonana została adaptacja układu zasilania, co pozwoliło na bezinwazyjną zamianę paliwa zasilającego silnik [12].

\section{Budowa modelu ocenowego}

Na podstawie analizy literatury przedmiotu $[1,9,11,13]$ oraz badań własnych ustalono, że oceny funkcjonowania środków transportu zasilanych mieszankami oleju napędowego i estrów metylowych kwasów tłuszczowych dokonuje się na podstawie badania istotnych parametrów (cech), wyrażonych za pomocą ich wartości liczbowych. Ocenie poddaje się te parametry, które ze względu na istotność i wpływ na wynik badania przyjęto w formalnym, matematycznym opisie modelu.

Ustalono, że proces oceny polega na ustaleniu zbioru $\left\{\mathrm{X}_{\mathrm{i}}\right\} \quad i=1,2, \ldots, p$ parametrów (cech) opisujących obiekt badań, wyznaczonych z punktu widzenia postawionego celu badania. Następnie należy dokonać pomiaru wartości każdego z przyjętych parametrów (cechy mierzalne) lub określić stan, w którym one się znajdują (cechy niemierzalne) poprzez przyporządkowanie im odpowiednich wyróżników. Na tej podstawie można określić stan eksploatacyjny jednostki napędowej środka transportu zasilanego mieszankami oleju napędowego i estrów metylowych kwasów tłuszczowych.

Niech $X_{i}, i=1,2, \ldots, p$, oznacza cechę będącą zmienną losową, która odzwierciedla ocenę funkcjonowania środka transportowego z punktu widzenia zasilania go określoną mieszanką paliwową. Rozważa się wektor cech postaci:

$$
\mathrm{X}=<\mathrm{X}_{1}, \mathrm{X}_{2}, \ldots, \mathrm{X}_{\mathrm{p}}>
$$

Składowa $X_{i}, i=1,2, \ldots, p$, wektora $X$ jest jednowymiarową zmienną losową w przestrzeni $R$, opisującą $i$-tą cechę odzwierciedlającą wartość jednego z parametrów przyjętych do oceny. Przy czym wektor $X$ jest $p$-wymiarową zmienną losową opisującą całościowo (zbiorczo) ocenę obiektu badań w przestrzeni $R^{p}$.

Dla danego obiektu badań definiuje się zmienną losową w postaci: 


$$
Z_{x}=\sum_{i=1}^{p} \alpha_{i} X_{i}
$$

gdzie:

$\alpha_{i} \geq 0, \sum_{i=1}^{p} \alpha_{i}=1$,

$\alpha_{i}, i=1,2, \ldots, p-$ oznaczają wartości wag dla poszczególnych parametrów,

$Z_{X}-$ jest zmienną losową, będącą skończoną mieszaniną zmiennych $X_{i}, i=1,2, \ldots, p$.

W procesie ocenowym do wyznaczenia wag poszczególnych kryteriów zastosowano metody AHP (Analytic Hierarchy Process) [10,18].

W niniejszych rozważaniach badanie polega na ocenie porównawczej środka transportu zasilanego różnymi mieszankami w odniesieniu do mieszanki znormalizowanej lub przyjętej jako punkt odniesienia. Należy zauważyć, że wartości parametrów opisujących badane próbki mogą być mniejsze, równe lub większe od wartości parametrów stanowiących punkt odniesienia. W takim przypadku, w interpretacji graficznej, długości składowych wektora $\bar{W}$ mogą być analogicznie różne od składowych wektora $\overline{W_{B}}$ lub im równe, a całościowa ocena $\overline{\Delta Q}$ będzie wynikała $\mathrm{z}$ sumarycznych wartości poszczególnych parametrów oraz przypisanych im wag.

W zbudowanym modelu przez zmienną $X$ oznaczono wektory jednowymiarowe, które przyjęto jako zmienne losowe. Badane parametry $\left(X_{1} \div X_{10}\right)$, przedstawione w tabeli 1 , odzwierciedlają ocenę środków transportu zasilanych mieszankami oleju napędowego ze zmiennym udziałem estrów metylowych kwasów tłuszczowych. Rozważany wektor przyjmuje wówczas postać:

$$
\mathrm{X}_{\mathrm{i}}=<\mathrm{X}_{1}, \mathrm{X}_{2}, \mathrm{X}_{3}, \mathrm{X}_{4}, \mathrm{X}_{5}, \mathrm{X}_{6}, \mathrm{X}_{7}, \mathrm{X}_{8}, \mathrm{X}_{9}, \mathrm{X}_{10}>
$$

Dla obiektu badań zdefiniowano zmienną losową, która przyjmuje postać:

$$
Z_{x}=\alpha_{1} X_{1}+\alpha_{2} X_{2}+\alpha_{3} X_{3}+\alpha_{4} X_{4}+\alpha_{5} X_{5}+\alpha_{6} X_{7}+\alpha_{7} X_{7}+\alpha_{8} X_{8}+\alpha_{9} X_{9}+\alpha_{10} X_{10}
$$

gdzie przez $\alpha$ oznaczono wartości wag dla poszczególnych parametrów, które przedstawione zostały w tabeli 1 .

Tabela 1

\section{Wartości wag dla poszczególnych parametrów}

\begin{tabular}{||l|l|l|l||}
\hline \hline Parametry & \multicolumn{1}{|c|}{ Oznaczenie } & \multicolumn{1}{|c|}{ Wyjaśnienie } & \multicolumn{1}{c|}{ Waga } \\
\hline $\mathrm{X}_{1}$ & $\alpha_{1}$ & moc [kW] & 0,2616 \\
\hline $\mathrm{X}_{2}$ & $\alpha_{2}$ & moment obrotowy [Nm] & 0,45547 \\
\hline $\mathrm{X}_{3}$ & $\alpha_{3}$ & $\begin{array}{l}\text { emisja dźwięku generowanego przez jednostkę } \\
\text { napędową [dB] }\end{array}$ & 0,01239 \\
\hline $\mathrm{X}_{4}$ & $\alpha_{4}$ & cząstki stałe zawarte w spalinach [ppm] & 0,2616 \\
\hline $\mathrm{X}_{5}$ & $\alpha_{5}$ & tlenek węgla [\% obj.] & 0,00044 \\
\hline
\end{tabular}


cd. tab. 1

\begin{tabular}{|l|l|l|l||}
\hline Parametry & \multicolumn{1}{|c|}{ Oznaczenie } & \multicolumn{1}{|c|}{ Wyjaśnienie } & Waga \\
\hline $\mathrm{X}_{6}$ & $\alpha_{6}$ & dwutlenek węgla [\% obj.] & 0,00235 \\
\hline $\mathrm{X}_{7}$ & $\alpha_{7}$ & tlen [\% obj.] & 0,00046 \\
\hline $\mathrm{X}_{8}$ & $\alpha_{8}$ & tlenki azotu [ppm] & 0,00539 \\
\hline $\mathrm{X}_{9}$ & $\alpha_{9}$ & współczynnik nadmiaru powietrza lambda & 0,00019 \\
\hline $\mathrm{X}_{10}$ & $\alpha_{10}$ & węglowodory [ppm] & 0,00011 \\
\hline
\end{tabular}

Na podstawie zrealizowanych badań eksploatacyjnych wyznaczono wartości średnie poszczególnych parametrów, w zależności od zastosowanej mieszanki paliwowej.

Wyznaczone wartości dla rozpatrywanych parametrów przekodowano w ten sposób, że wartości minimalne odzwierciedlają najgorszy ich poziom, natomiast wartości maksymalne odzwierciedlają pożądaną wartość poszczególnych parametrów.

W celu przejrzystości i jednoznaczności otrzymanych wyników, dla zbioru analizowanych parametrów dokonano unormowania ich wartości na przedział $<0 \div 10>$, korzystając z następującej zależności:

$$
10 \times \frac{\left(X_{i}-X_{\min }\right)}{\left(X_{\max }-X_{\min }\right)}
$$

$\mathrm{Na}$ tej podstawie wyznaczono wartości wektorów dla poszczególnych parametrów eksploatacyjnych badanej jednostki i porównano je z wartościami dla „czystego oleju napędowego", stanowiącego w niniejszych rozważaniach punkt odniesienia.

Przykładowa interpretacja wyników w postaci graficznej dla miesznki II, została przedstawiona na rys. 1 .

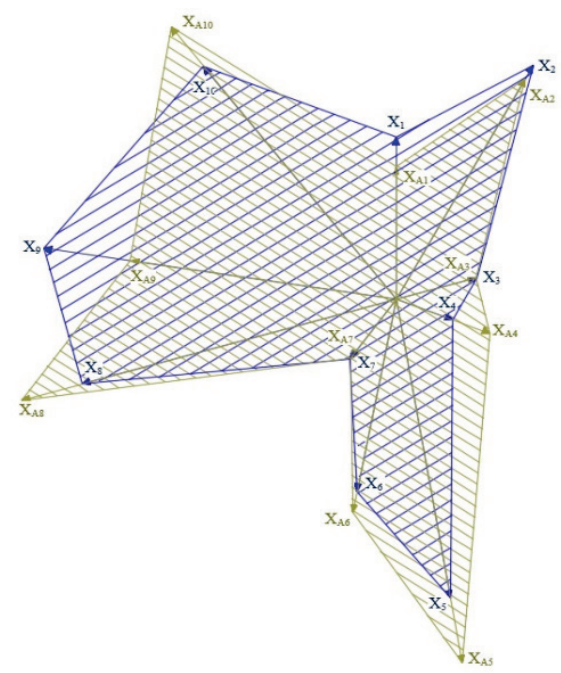

Rys. 1. Interpretacja graficzna składowych wektora dla mieszanki II 


\section{Weryfikacja zbudowanego modelu}

W metodologii prezentowanego w opracowaniu procesu ocenowego jednym z podstawowych problemów jest wyznaczenie ze zbioru analizowanych parametrów tylko tych, które mają najistotniejszy wpływ na realizowaną ocenę i stanowią podstawę do dalszych analiz. W zbudowanym modelu wynikowym wyróżniono zbiór dziesięciu parametrów. Mając na uwadze weryfikację zbudowanego modelu, a w szczególności sprawdzenie nadmiarowości przyjętego zbioru parametrów oraz wyznaczenie ich istotności, proponuje się zastosowanie metody wykresów średnich rozmytych. Modelowania rozmytego dokonano na podstawie analizy wartości parametrów użytkowych, wyznaczonych w wyniku zrealizowanych badań eksploatacyjnych. Dla wybranych wartości każdego z przyjętych parametrów wyznaczono przekrój przez powierzchnię, dla ustalonej wartości zmiennej $[13,16]$.

W celu analizy rzeczywistych danych dokonano rozmycia wartości ustalonej dla przekroju punktami pomiarowymi. Eliminuje to problemy związane z nierównomiernym i nieciągłym pokryciem przestrzeni rozwiązań. Przynależność punktu pomiarowego do danego przekroju przyjęto w postaci funkcji Gaussa:

$$
\mu\left(X_{i}^{*}\right)=\exp \left(-\left(\frac{X_{i}^{*}-X_{i}}{b}\right)^{2}\right)
$$

gdzie:

$\mu\left(X_{i}^{*}\right)$ - funkcja przynależności dla wartości ustalonej $i$-tego parametru,

$X_{i}^{*} \quad$ - wartość ustalona $i$-tego parametru,

$b \quad-$ szerokość rozwarcia funkcji przynależności.

Dla każdego przekroju obliczono wartość średnią ważoną:

$$
Z_{\text {śr } r}\left(X_{i}\right)=\frac{\sum_{k=1}^{n w p} \mu\left(X_{k}\right) \times Z\left(w p_{k}\right)}{\sum_{k=1}^{n w p} \mu\left(X_{k}\right)}
$$

gdzie:

nwp - liczba wektorów pomiarowych,

$w p \quad-$ wektor pomiarowy.

Wartości średnie przekrojów tworzą krzywą, której rozrzut jest miarą stopnia zależności wartości wyjściowej modelu od wartości wejściowej.

W trakcie realizacji prac wykonano analizę za pomocą oprogramowania [17], dostostrojonego do potrzeb niniejszego opracowania. Przyjęto współczynnik rozpiętości funkcji przynależności owartości 20\%. Ustalono liczbę przekrojów rozmytych równą 10 oraz opracowano metodę obliczania rozrzutu jako wartości średniokwadratowej. Na bazie przeprowadzonej analizy postaci gradientowej średnich rozmytych jako granicę istotności przyjęto wartość równą 0,01 . Ustalono równe wagi dla wszystkich badanych parametrów 
użytkowych, a następnie określono, które parametry są najistotniejsze w świetle przeprowadzonego eksperymentu. Tak uzyskane wyniki poddano analizie poprzez wyzaczenie średnich rozmytych w celu określenia parametrów wrażliwych na zmiany. $\mathrm{Na}$ rys. 2 przedstawiono postać widmową średnich rozmytych. Na podstawie analizy uzyskanych danych oraz ich interpretacji graficznej można przyjąć, że parametry użykowe, których wartość rozrzutu jest mniejsza od $0,04 \mathrm{w}$ istotny sposób nie ulegają zmianie w zależności od rodzaju paliwa, którym zasilano jednostkę napędową badanego środka transportu.

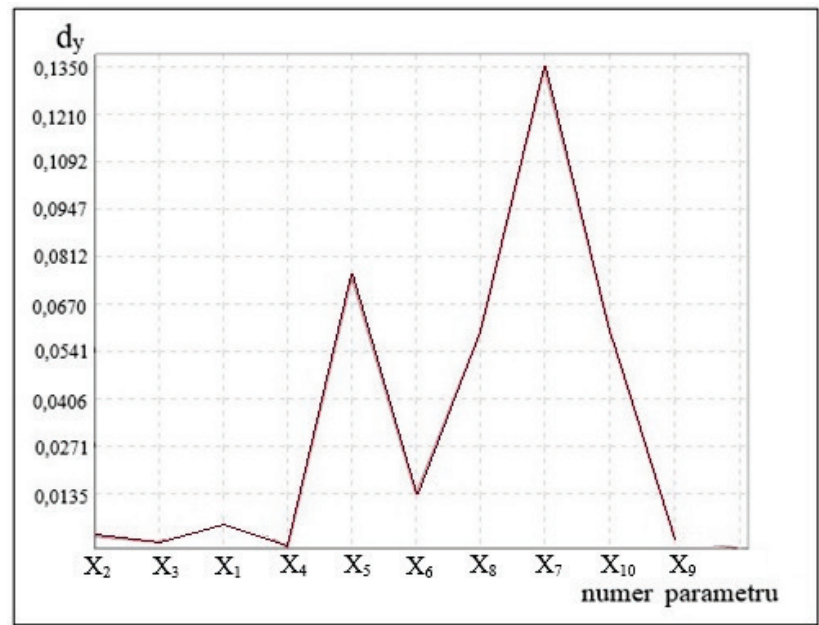

Rys. 2. Postać widmowa średnich rozmytych

Wartości uzyskanych rozrzutów dla poszczególnych parametrów użytkowych, określające ich wrażliwość na zmiany składu mieszanki, przedstawiono w tabeli 2.

Tabela 2

Wartości rozrzutu średnich rozmytych dla poszczególnych paramatrów użytkowych

\begin{tabular}{|l|c|l||}
\hline \hline Rodzaj parametru & Oznaczenie & Wartość rozrzutu średniej rozmytej \\
\hline moc [kW] & $\mathrm{X}_{1}$ & 0,0035 \\
\hline moment obrotowy [Nm] & $\mathrm{X}_{2}$ & 0,0019 \\
\hline hałas [dB] & $\mathrm{X}_{3}$ & 0,0012 \\
\hline cząstki stałe [ppm] & $\mathrm{X}_{4}$ & 0,0002 \\
\hline tlenek węgla [\% obj.] & $\mathrm{X}_{5}$ & 0,0755 \\
\hline dwutlenek węgla [\% obj.] & $\mathrm{X}_{6}$ & 0,0138 \\
\hline
\end{tabular}


cd. tab. 2

\begin{tabular}{||l|c|l||}
\hline Rodzaj parametru & Oznaczenie & Wartość rozrzutu średniej rozmytej \\
\hline tlen [\% obj.] & $\mathrm{X}_{7}$ & 0,1353 \\
\hline tlenki azotu [ppm] & $\mathrm{X}_{8}$ & 0,0605 \\
\hline $\begin{array}{l}\text { współczynnik nadmiaru } \\
\text { powietrza }\end{array}$ & $\mathrm{X}_{9}$ & 0,0029 \\
\hline \begin{tabular}{l} 
węglowodory [ppm] \\
\hline
\end{tabular} & $\mathrm{X}_{10}$ & 0,0596 \\
\hline
\end{tabular}

Dane przedstawione w tabeli mogą stanowić podstawę do wnioskowania, który z badanych parametrów użytkowych był wrażliwy na zmianę mieszanki paliwowej i czy wzwiązku z tym, w dalszych opracowaniach w budowie modelu wynikowego można go pominąć.

W wyniku analizy danych wyznaczonych po zastosowaniu metody wykresów średnich rozmytych zweryfikowano postać wynikową modelu ocenowego. $\mathrm{Na}$ tej podstawie wyróżniono i uwzględniono $\mathrm{w}$ dalszych badaniach zbiór sześciu parametrów, które charakteryzowały się znacznym rozrzutem wartości otrzymanych wyników. Wartości pozostałych parametrów użytkowych (moc, moment obrotowy, emisja dźwięku, cząstki stałe) pominięte zostały w opracowanym modelu z uwagi na ich niewielką wrażliwość na wprowadzane zmiany składu mieszanki paliwowej.

W związku z powyższym, rozpatrywany wektor parametrów $X_{i}$ przyjmuje postać:

$$
\mathrm{X}=<\mathrm{X}_{5}, \mathrm{X}_{6}, \mathrm{X}_{7}, \mathrm{X}_{8}, \mathrm{X}_{9}, \mathrm{X}_{10}>
$$

\section{Wnioski}

Analizując powyższe wyniki badań, stwierdzono, że metoda wykresów średnich rozmytych stanowi istotne narzędzie w analizowanym procesie ocenowym.

Niniejsza weryfikacja wykazała, że wstępnie zakładana liczność oraz istotność parametrów użytkowych przyjętych do oceny badanej jednostki napędowej nie znalazła odzwierciedlenia w ich wrażliwości na zadane zmiany ilości dodatków biokomponentów do paliwa. W związku z tym, uzyskane wyniki badań umożliwiły ustalenie ważności rozpatrywanych parametrów z przyjętego punktu widzenia, ograniczenie wymiarowości rozpatrywanej przestrzeni - zbioru parametrów oraz wyznaczenie postaci wynikowej modelu ocenowego. Należy jednocześnie zauważyć, że następstwem zrealizowanych badań są korzyści związane z ograniczeniem kosztów oraz czasu, niezbędnych do ich dalszej realizacji. 


\section{Literatura}

1. Aryanto D.: Research of Simple Multi-Attribute Rating Technique for Decision Support. JITEKH (Jurnal Ilmiah Teknologi Harapan), 2019, 1.

2. Asadia A., Zhangb Y., Mohammadi H., Khorand H., Rui Z., Hossein Doranehgard M., Bozorge M.: Combustion and Emission Characteristics of Biomass Derived Biofuel, Premixed in a Diesel Engine: A CFD Study. Renewable Energy, Vol. 138, 2019.

3. Baraniak M., Laczek T.: Low temperature properties of biofuels containing fatty acid methyl esters of animal fat origin. Oil-Gas, 2010.

4. Beran E.: Chemical technology - Energy resources and methods. Wrocław University of Technology, 2013.

5. Fontaras G., Karavalakis G., Kousoulidou M., Tzamkiozis T., Ntziachristos L., Bakeas E., Stournas S., Samaras Z.: Effects of Biodiesel on Passenger Car Fuel Consumption, Regulated and Non-Regulated Pollutant Emissions Over Legislated and Real-World Driving Cycles. Fuel, Vol. 88, 2009.

6. Gang W., Guohe J., Zhiyuan Y., Zhijian H.: Emission Characteristics for Waste Cooking Oil Biodiesel Blend in a Marine Diesel Propulsion Engine. Polish Journal of Environmental Studies, Vol. 28, 2019.

7. Jakóbiec J., Baranik M., Duda A.: High quality of fatty acid methyl esters of rape oil is a promotion of car transport. Archives of Motorization, Warsaw, 2008.

8. Landowski B., Baran M.: Analysis of selected results of engine oil tests. 18th International Conference Diagnostics of Machines and Vehicles, MATEC Web of Conferences, 302, 2019.

9. Landowski B., Pająk M., Żółtowski B., Muślewski Ł.: Method of building a model of operational changes for the marine combustion engine describing the impact of the damages of this engine on the characteristics of its operation process. Polish Maritime Research, no. 4 (96), vol. 24, 2017.

10. Lootsma F.A.: A model for the relative importance of the criteria in the multiplicative AHP and Smart. European Journal of Operational Research, No. 94, 1996

11. Markiewicz M., Muślewski Ł., Pająk M.: Impact of Biocomponent Additive to Diesel Oil on Values of Selected Functional Parameters of Transport Means. Polish Journal of Environmental Studies, Vol. 29, 2020.

12. Markiewicz M., Muślewski Ł.: The impact of powering an engine with fuels from renewable energy sources including its software modification on a drive unit performance parameters, Sustainability. Vol. 11, Iss. 23, 2019.

13. Markiewicz M., Muślewski Ł.: Survey performance and emission parameters of diesel engine powered by diesel oil and fatty acid methyl esters using fuzzy logic techniques. Fuel, Vol. 277, 2020.

14. Mofijur M., Rasul M., Hyde J., Bhuyia M.: Role of Biofuels on IC Engines Emission Reduction. Energy Procedia, Vol. 75, 2015. 
15. Radziemska E., Lewandowski W., Szukalska E., Tynek M., Pustelnik A., Ciunel K.: Rape biofuels, preparation of raw material to provide biocomponents under the conditions of an agricultural farm and pilot methanolysis. Metrologia, Gdańsk 2009.

16. Pająk, M.: Genetic-Fuzzy system of power units maintenance schedules generation. J Intell Fuzzy System, 28, 2015.

17. Pająk M., Muślewski Ł., Landowski B., Grządziela A.: Fuzzy identification of the reliability state of the mine detecting ship propulsion system. Polish Maritime Research, 26 (1), 2019.

18. Saaty T.L.: The analytic Hierarchy Process. Planning, priority setting and resource allocation. Mc. Graw-Hill, New York 1980.

19. Struś M.: Efficiency of self-ignition combustion engines powered with bioxdiesel with totally recyclable components, Machine Engineering, 2014.

20. Tys J., Piekarski W., Jackowska I., Kaczor A., Zając G., Starobrat P.: Technological and economic conditionings of rape biofuel production, Disputes and monographs, Lublin 2003.

21. Uzdowski M.: Possibilities of using mixtures of traditional and alternative fuels to power ZS engines. Motrol 8A, 2006. 